\title{
Bargaining agenda in a unionised monopoly with network effects: when corporate social responsibility may be welfare-reducing
}

\author{
Luciano Fanti ${ }^{1} \cdot$ Domenico Buccella $^{2}$
}

Received: 12 April 2016/Accepted: 22 December 2016/Published online: 6 January 2017

(C) The Author(s) 2017. This article is published with open access at Springerlink.com

\begin{abstract}
This paper investigates the bargaining agenda selection in a socially concerned unionised monopoly producing a network good. We show that the recently established result that under network effects the firm prefers sequential efficient bargaining may be reversed when there are social concerns. Thus, firm's social responsibility restores also in network industries the conventional result of the trade-union economics that the firm prefers right-to-manage (RTM). However, this may result rather paradoxical because RTM is always welfare-inferior and thus the higher the social responsibility is, the lower the social welfare outcome due to the agenda selection. As a consequence an increase of the firms' social concerns in network industries may reduce, through the channel of the unionised labour market, social welfare, in contrast with the common sense. This sheds some light on so far unexplored effects of the promotion of social responsibility activities by policy makers when also labour markets are taken into account.
\end{abstract}

Keywords Efficient bargaining $\cdot$ Right-to-manage $\cdot$ Firm-union bargaining agenda Corporate social responsibility $\cdot$ Network effects

Electronic supplementary material The online version of this article (doi:10.1007/s40888-016-00511) contains supplementary material, which is available to authorized users.

Domenico Buccella

buccella@kozminski.edu.pl

Luciano Fanti

luciano.fanti@unipi.it

1 Department of Economics and Management, University of Pisa, Via Cosimo Ridolfi, 10, 56124 Pisa, PI, Italy

2 Department of Economics, Kozminski University, Jagełłonska Street, 57/59, 03301 Warsaw, Poland 
JEL Classification J51 $\cdot$ L12 $\cdot$ L21 $\cdot$ M14

\section{Introduction}

Two stylised facts have involved firms' behaviours in recent decades. On the one hand, corporate social responsibility (CSR) has generated a large amount of interest in the economics and management literature (see, e.g., the survey article of Carroll and Shabana 2010). ${ }^{1}$ On the other hand, network industries are among the fastest developing sectors of advanced modern economics.

With regard to the firms' CSR behaviours, numerous reports have witnessed an increasing trend of this phenomenon: for instance, the KPMG Survey of Corporate responsibility $(\mathrm{Cr})$ in 2013 observes that "this year the research is more broadranging than ever, covering 4100 companies across 41 countries (the last survey in 2011 looked at 3400 companies in 34 countries)...the growth in the number of countries and companies covered in this survey is just one indication of how $\mathrm{Cr}$ reporting has evolved into a mainstream business practice over the last two decades." (KPMG 2013, 3). In particular, as regards countries showing this trend "..large companies in Italy, Spain and the UK lead the world for the quality of $\mathrm{Cr}$ reports. European G250 companies achieve the highest average quality score for their $\mathrm{Cr}$ reports at 68 out of 100. This compares with average scores of 51 for companies in the Americas and 48 in Asia Pacific." (KPMG 2013, 17). The economy of social and environmental sustainability plays a crucial role in the European Union, as is clearly shown by the fact that more than $10 \%$ of the total European Economy (in terms of GDP), with more than 11 millions of workers $(6 \%$ of total employment) belongs to this sector.

With regard to the relevance of network goods in modern economies, one may think the large-scale expansions of, for example, telephones, mobile devices and software: it is natural to observe that the utility of a particular consumer from using those goods increases with the number of other users. ${ }^{2}$ Moreover, it is important to note that most giant firms in network industries are distinctly oriented towards CSR behaviours, so that the production of network goods and the exercise of CSR behaviours goes hand in hand. In fact, according to the Reputation Institute Global CSR survey, among the world's top ten companies with the best CSR reputations, large multinationals active in network industries are prevailing, as Table 1 shows, which reports the top 10 companies of the past 3 years of the Global CSR RepTrak ${ }^{\circledR}$ (Reputation Institute 2015).

\footnotetext{
${ }^{1}$ One definition of CSR is as follows: 'a concept whereby companies integrate social and environmental concerns in their business operations and in their interaction with their stakeholders on voluntary basis' (European Commission 2001).

${ }^{2}$ In general, network goods are products in which the utility one consumer/user derives increases with the number of other consumers/users of that goods. Put differently, the total sales of the goods enhance the welfare of each consumer. In addition, the number of other consumers/users of the product may directly influence the demand for the network goods because it may represent the product quality and availability of after-sale services for long-lasting consumers. More in general positive network externality may exist for those products which a consumer wishes to possess in part because others do (i.e. the socalled Bandwagon Effect), for instance products of fashion industry.
} 
Table 1 Global CSR RepTrak ${ }^{\circledR}$ : top 10 past 3 years

\begin{tabular}{llll}
\hline & 2015 & 2014 & 2013 \\
\hline 1 & Google & Google & Microsoft \\
2 & BMW & Microsoft & The Walt Disney Company \\
3 & The Walt Disney Company & The Walt Disney Company & Google \\
4 & Microsoft & BMW & BMW \\
5 & Daimler & Apple & Daimler \\
6 & Lego & Lego & Sony \\
7 & Apple & Volkswagen & Intel \\
8 & Intel & Intel & Volkswagen \\
9 & Rolls-Royce & Rolex & Apple \\
10 & Rolex & Daimler & Nestle' \\
\hline
\end{tabular}

Bold indicates the companies operating in network industries

Moreover, a growing literature in industrial organisation has recently recognized the crucial role played by unions in oligopolies (see, for example, Dowrick 1989, 1990; Horn and Wolinsky 1988; López and Naylor 2004). Given the importance of network industries in contemporary economy, it is timely to investigate what is the impact of unionisation in those sectors. Several large companies in those industries (e.g., Silicon Valley giants such as Microsoft, Google, Yahoo and Apple) are mainly not unionised. However, workers have recently been able to form unions in those companies. For instance, in early March 2015, due to recently passed legislation in California, Apple bowed to pressure from the labour union SEIU-USWW and agreed to directly employ security guards on its Cupertino, California, campus instead of hiring the work out through a subcontractor. Then, Facebook shuttle drivers gained final approval for their union contract (Al Jazeera America 2015). In September 2015, 38 bug tester who work full time in Microsoft's offices to review apps voted to create a union, the Temporary Workers of America (BloombergBusinessweek 2015). Therefore, if the workforce in large CSR companies in network industries is to become unionised, it is rather natural to investigate the impact of bargaining for those companies and the overall welfare.

A classical result in the unionised firm literature is that profits are higher when firms bargain only over wage and choose employment (right-to-manage, RTM) with respect to the ones when they also bargain over employment (simultaneous, EB, or sequential efficient bargaining, SEB) (Naylor 2003). ${ }^{3}$ Indeed, a central issue of labour market institutions in advanced economies is the selection of the bargaining

\footnotetext{
${ }^{3}$ Dowrick (1990) has first analysed the subject of the more profitable bargaining agenda in the context of unionised industries. That author has found "that profits under the RTM model exceed those under Efficient Bargaining" (Naylor 2003, pag. 59). Moreover, from the comparison of the RTM and SEB bargaining outcomes, the conventional result argues that "under unionised monopoly, the firm will prefer to keep employment off the bargaining agenda whatever the degree of union influence over employment. In other words, the right-to-manage outcome generates higher profits than either the efficient or sequential bargains, for a given level of union influence over the wage" (Naylor 2003, pag. 61).
} 
agenda between firms and unions, and the rise of possible conflicts of/common interest among the bargaining parties. Other established results of the unionised firm literature are that unions (and consumers) always prefer the EB agenda and thus a (possibly undesirable) conflict of interest between the bargaining parties (and agents) always occurs (Bughin 1999; Buccella 2011).

A few papers have recently revisited the selection of the bargaining agenda (Fanti 2015; Buccella and Fanti 2015; Fanti and Buccella 2015, 2016). In particular, Fanti and Buccella (2016) analyse the choice of the bargaining agenda in a unionised monopoly with network effects. Those authors show that, in contrast to the established result that in pure monopoly the firm always chooses RTM, a SEB agreement is preferred, provided that the intensity of the network is sufficiently strong. Such a result means that in network goods industries the firm's choice of the SEB arrangement allows to eliminate the conflict of interests between different agents and achieve a Pareto-superior outcome. However, none of the previous contributions considers the presence of CSR firms.

Despite the relevance of both positive consumption externalities and CSR, issues pertaining to network goods industries with CSR rules, to the best of our knowledge, are scanty in the literature on unionised industries. In this paper we aim to fill this gap. An objective of the paper is to investigate whether firms' engagement in CSR activities is always desirable from a social welfare point of view when labour market institutions are considered. Scholars ${ }^{4}$ as well as policy-makers ${ }^{5}$ claim that CSR activities have positive effects on social welfare. Moreover it has been also argued that a direct social-welfare-enhancing effect may stem from the emergence of the CSR phenomenon through its role in mitigating market failures as substitutive of a socially costly market regulation, ${ }^{6}$ as noted by Valach $(2015,1705)$ : "From a welfare point of view, promoting corporate social responsibility can be an alternative or complementary way for regulation to confront market failures. Regulation is costly; it has limitations originating from asymmetric information and political constraints. It also has a limited impact over global public goods (global warming, Amazon deforestation, biodiversity loss, or child labour). Corporate social responsibility can reach where national regulations fall short and have a great impact on our wellbeing."

Given the relevant presence of CSR firms in Europe, European policy makers are actively working for a further promotion of firms' social concerns. ${ }^{7}$ Since the

\footnotetext{
${ }^{4}$ For instance, Frank (2003) argues that social concerns increase social welfare by enhancing the "common good.".

5 For instance its promotion is clearly affirmed by policy-makers in Europe (European Commission 2006, 2011).

6 The idea that CSR can prevent market failures such as firms' power market and environmental externality, and thus constitute an alternative instrument with respect to the traditional one of markets regulation generally used to prevent such failures has been developed by Calveras et al. (2007) and Ganuza (2012).

${ }^{7}$ For instance, "on October 2011 the European Commission has adopted a Social Business Initiative action plan as part of a package of measures entitled the "Responsible Business Initiative" (see IP/11/ 1238) which will help this emerging sector to fulfill its potential. This initiative is complemented by an ambitious strategy for Corporate Social Responsibility to generate a higher level of trust and consumer confidence and improve companies' contribution to societal well-being. The aim of the Social Business
} 
promotion of CSR is high on the policy agenda for sustainable development in many countries, then it is of interest-especially for European countries which have a sizable presence of both CSR firms and unionised firms - to investigate so far unexplored effects of CSR rules such as those on the choice of the bargaining agenda.

More in detail, we want to answer the following research questions: first, how does firms' social concern change the above mentioned result under network effects? Second, how are the agents' and societal welfares affected by the modification of the agenda's choice induced by firms' social concerns?

Indeed, the main result is that, rather surprisingly, the adoption of CSR rules by firms restores the classical bargaining agenda result. Thus, since the RTM agenda is welfare-reducing, we show that, through this channel, the expected welfareenhancement effects occur because of the CSR activities' promotion is challenged.

The remainder of the paper is organised as follows. Section 2 presents the basic monopoly-union bargaining model and then presents and discusses the results. Finally, the last section summarises the main results and their welfare implications and suggests directions for further research on the subject.

\section{The model}

The monopolist's profit function is:

$$
\pi=(p-c-w) q,
$$

where $p$ is the price of good, $w$ is the wage per unit of output and $c$ is the marginal cost (for inputs different from the labour).

As Katz and Shapiro (1985) assume, the simple mechanism describing here the network effects is that the surplus a firm's client gets directly increases with the number of other clients of this firm. We strictly follow Fanti and Buccella (2016) ${ }^{8}$ by assuming that the monopolist faces the following linear direct demand:

$$
q=a-p+n y,
$$

where $q$ denotes the quantity of the goods produced, $y$ denotes the consumers' expectation about monopolist's equilibrium production, ${ }^{9}$ the parameter $n \in[0,1)$

\footnotetext{
Footnote 7 continued

Initiative is to support those social businesses whose mission is to generate significant social, environmental and community impacts for a more sustainable economic growth. When launching the initiative the EU remarked that one out of four new firms in Europe are "social business". " (Becchetti et al. 2014, 4).

8 The interested reader is referred to that work for further details.

9 Note that we strictly follow here the assumptions of Katz and Shapiro (1985). However, as also Katz and Shapiro (1985, Appendix A) and Amir and Lazzati (2011) notice, in some contexts firms may be able to commit strongly to a product level before consumers decide their purchases (only the equilibrium production levels are credible announcements). In such cases the effect of the monopolist production decisions without consumers' expectations may lead to different equilibrium outcomes. This extension is left for future research.
} 
indicates the strength of network effects (i.e., the higher the value of the parameter is, the stronger the network effects are). The inverse demand function is:

$$
p=a-q+n y
$$

We also assume that the firm has social concerns, i.e. the shareholder value is combined with stakeholders' interests. This combination leads to a broader firm objective function which is modelled following previous analytical frameworks (e.g. Goering 2007, 2008, 2012, 2014; Kopel and Brand 2012; Lambertini and Tampieri 2010, 2011). More precisely, we assume that, additionally to its profit, $\pi$, the firm takes also care of the consumer surplus, CS. Hence, the firm's objective function, $W$, can be rewritten as

$$
W=\pi+r C S=(a-q-c-w+n y) q+r \frac{\left(q^{2}-n y^{2}\right)}{2},
$$

where $r \in[0,1]$ indicates the weight put on consumer surplus ("the social concern"). For $r=0$, the monopolist operates like a profit maximising while, for $r=1$, the whole consumer surplus is considered in the firm's objective function. ${ }^{10}$

\subsection{The union behaviour}

The efficient bargaining may be either simultaneous over wage and employment (EB) (McDonald and Solow 1981) or sequential, first over wage and then over employment (SEB) (Manning 1987a, b). Under EB, the monopolist-union unit simultaneously bargains over wages $w$ and quantity $q$ to maximise the Nash product. On the other hand, under RTM, the monopolist-union unit first bargains over wages $w$ to maximise the Nash product; however, in the subsequent stage, the firm has the right to select output and, therefore, employment.

Moreover, following Katz and Shapiro (1985) and the recent literature on network goods (Hoernig 2012; Chirco and Scrimitore 2013; Bhattacharjee and Pal 2014), we impose the additional "rational expectations" conditions, that is consumers fulfil their expectations at equilibrium (i.e. $y=q$ ). As usual, our equilibrium concept is the subgame-perfect Nash equilibrium, and we solve this game by the backward induction method.

In the present paper, we compare the SEB with the RTM model. The rationale for this choice resides in the fact that with those two models, consumers fulfil their expectations about the network size exactly at the same stage of the game, as shown in Fig. 1.

In the RTM and SEB cases, monopolist's decisions are taken in two different stages. In the first stage, the monopolist-union unit bargains over wages $w$ to maximise the Nash product. In the second stage, consumers fulfil their expectations. Finally, in the

\footnotetext{
10 Thus, the stakeholders' participation in governance is only relevant to market decisions. In other words, stakeholders exerts "pressure" with regard to the firm's objective; however, private owners make the company's strategic decisions. This assumption is consistent with the empirical findings of Spitzeck and Hansen (2010) that the stakeholders engagement mechanism is mainly limited to "dialogue \& issues" advisory while the strategic decisions of the company (like the choice of the bargaining agenda in the union-firm negotiations) are beyond their sphere.
} 


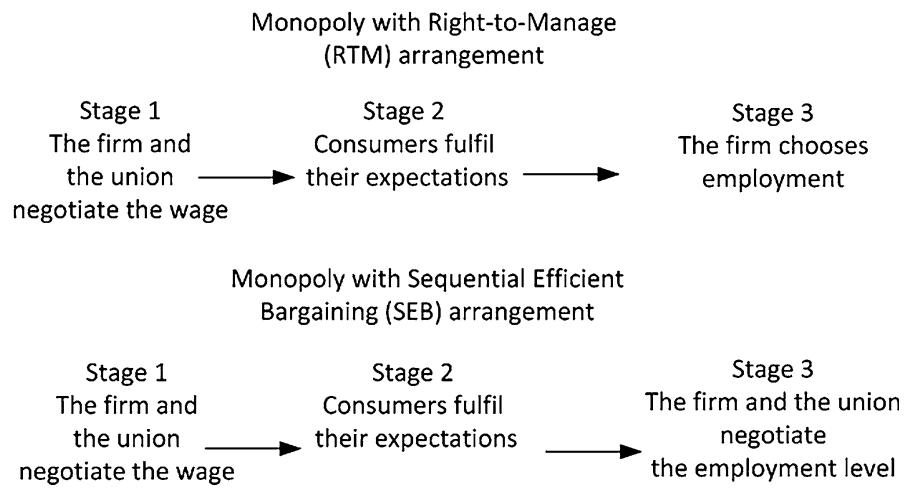

Fig. 1 Timing of the game

third stage (1) with RTM, the monopolist selects the quantity $q$ (alternatively, the price $p)$ to maximise profits, (2) with SEB, the monopolist-union unit negotiates over the quantity $q$ (alternatively, the price $p$ ) to maximise the Nash product.

The union utility function is $V=\left(w-w^{\circ}\right) l$ (e.g. Pencavel 1985), where $l$ is employment and $w^{\circ}$ the reservation wage. Given the standard assumption of constant returns to labour, $q=l$, it follows that

$$
V=\left(w-w^{\circ}\right) q .
$$

The following generalized Nash Product models the bargaining solution in the case of CSR firm

$$
N=W^{1-b} V^{b}
$$

where $b \in[0,1]$ represents the bargaining power of the union. Using Eqs. (1)-(5) and solving the Nash Product in Eq. (6), direct computations allow to derive the expressions in Table 2. The Appendix reports the extensive derivations. Based on the equilibrium outcomes for the alternative bargaining agendas in Table 2, we analyse the impact of the firm's engagement in CSR activities in a monopoly with network goods.

\subsection{Main results and their discussion}

Let us now carry out the analysis of CSR activities in network industries.

Assumption 1 To assure the non-negativity of all the variables of the model, the following inequalities hold throughout the paper:

$$
\text { 1) } \left.a \geq c+w^{\circ} ; 2\right) r^{\mathrm{T}, N E T} \leq \frac{2(1-b)}{2-(1+n) b}
$$

where the upper script NET stands for "network". Note that the presence of network externalities increases the critical value of the monopolist level of CSR activities $r^{T, N E T}$. 


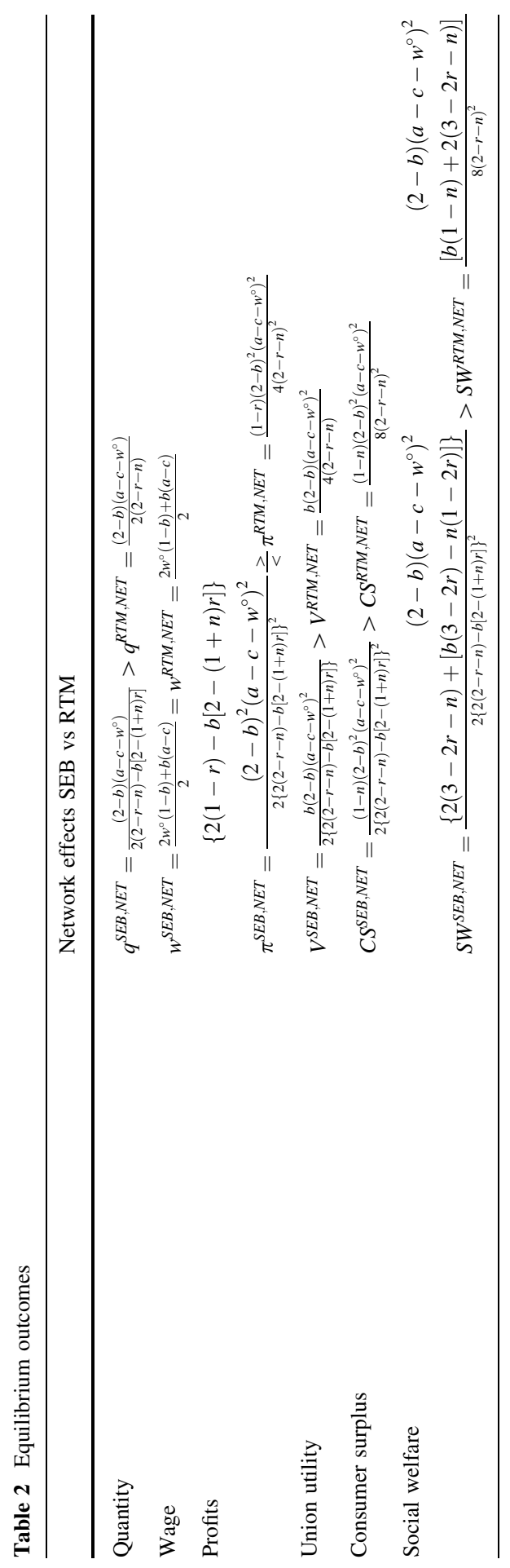


An analytical inspection shows that $\frac{\partial q^{R T M, N E T}}{\partial n}>0$ and $\frac{\partial q^{S E B, N E T}}{\partial n}>0$ : the network intensity boosts the monopolist to raise production. Therefore, the network effects complement the CSR engagement in stimulating output expansion, and further put downward pressure on the final price, regardless of the bargaining agenda. The impact of the network effects on output expansion (price reduction) under the SEB agenda is larger than the RTM, that is $\left|\frac{\partial q^{S E B, N E T}}{\partial n}\right|>\left|\frac{\partial q^{R T M, N E T}}{\partial n}\right|$. Further investigation reveals that, for $b \in[0,1], \frac{\partial^{2} q^{R T M, N E T}}{\partial n \partial r}=\frac{\partial^{2} q^{R T M, N E T}}{\partial r \partial n}>0$ and $\frac{\partial^{2} q^{S E B, N E T}}{\partial n \partial r}=\frac{\partial^{2} q^{S E B, N E T}}{\partial r \partial n}>0$ : under both agendas, the CSR engagement and the network effects reinforce each other in expanding output. In other words, those effects are complement on the output decision.

Let us now analyse the impact of CSR and network effects on profits. Differentiation shows that $\frac{\partial \pi^{R T M, N E T}}{\partial n}>0$ and $\frac{\partial \pi^{R T M, N E T}}{\partial r} \geq 0$ if $n \frac{>}{<} r_{1 r}^{R T M, N E T}$ : under the RTM agenda, the network effects always have a positive impact on profits; however, the level of social engagement has a positive effect on the firm's profitability only if its level is lower than the network intensity, as the threshold $r_{1 r}^{R T M, N E T}$ indicates (the first index denotes the first partial derivative, the second index with respect to which variable). The analysis of the mixed derivatives also reveals that $\frac{\partial^{2} \pi^{R T M, N E T}}{\partial n \partial r}=\frac{\partial^{2} \pi^{R T M, N E T}}{\partial r \partial n}>0$ if $\frac{1+n}{2}>r_{2}^{R T M, N E T}$ (the first index of the threshold indicates that it relates to the second partial derivative). However, given that $r_{2}^{R T M, N E T}>r_{1 r}^{R T M, N E T}$ for $n \in[0,1]$, whenever the level of social engagement has a positive impact on profits, the network effect has a complementarity effect on profitability.

As regards the SEB agenda, differentiation of the profit function with respect to the parameters $n$ and $r$ leads to $\frac{\partial \pi^{S E B, N E T}}{\partial n}>0$ if $\frac{4-b^{2}-b n-2 b-\sqrt{b^{4}-(6 n+4) b^{3}+\left(n^{2}+12 n+20\right) b^{2}-(8 n+32) b+16}}{b[2-(1+n) b]}<r_{1 n}^{S E B, N E T} \quad$ and $\quad \frac{\partial \pi^{S E B, N E T}}{\partial r} \geq 0$ if $\frac{2(n-b)}{2-(1+n) b}<r_{1 r}^{S E B, N E T}$ : under the SEB agenda, it exists an optimal value of both the network effects and CSR level, depending on the union bargaining power, that maximise profits. The analysis of the mixed derivatives shows that $\frac{\partial^{2} \pi^{S E B, N E T}}{\partial n \partial r}=$ $\frac{\partial^{2} \pi^{S E B, N E T}}{\partial r \partial n} \geq 0$ if $\frac{8-8 b-\sqrt{b^{4}-(6 n+4) b^{3}+\left(n^{2}+6 n+26\right) b^{2}-4(n+9) b+16}}{b[2-(1+n) b]}<r_{2}^{S E B, N E T}$.

Because for $n \in[0,1] \vee b \in[0,1]$ it holds that $r_{2}^{S E B, N E T}<r_{1 n}^{S E B, N E T}$, it follows that the level of social engagement has a complementarity effect on profits only up to a level of the network externalities lower than their optimal value.

On the other hand, given that $r_{2}^{S E B, N E T}>r_{1 r}^{S E B, N E T}$ for $n \in[0,1] \vee b \in[0,1]$, when the level of CSR has a positive impact on profits, the network effect always has a complementarity effect on profitability: in that case, the two forces work in the same direction to increase the monopolist's profits.

Now, we investigate if the network effects have an impact on the monopolist's bargaining agenda choice. Let us define $\Delta \pi^{N E T}=\pi^{S E B, N E T}-\pi^{R T M, N E T}$ and $\Delta V^{N E T}=V^{S E B, N E T}-V^{R T M, N E T}$. Then, we get 


$$
\begin{aligned}
& \Delta \pi^{N E T} \\
& =\frac{b(2-b)^{2}\left(a-c-w^{\circ}\right)^{2}[(1+n) r-2]\left\{r^{2}[b(1+n)-2]+r[4-b(3+n)]+2\left(n^{2}+b\right)-4 n\right\}}{4\{2(2-b-n)+r[(1+n) b-2]\}^{2}(2-n-r)^{2}},
\end{aligned}
$$

and it can be shown that $\Delta V^{N E T}>0$ in the relevant parameter space. An analytical and graphical inspection reveals the following result.

Result 1 When the firm's sensitivity to consumer surplus rises, the SEB agenda requires an increasing level of the network intensity to be preferred to RTM. However, given that SEB is always the union's preferred agenda, there is room to negotiate an agreement in common interest.

Corollary The presence of a strong union: (a) requires that the network effects have to be adequately intense to allow the bargaining parties to reach a common interest agreement toward the SEB agenda, i.e. the higher $b$ is, the less likely $\Delta \pi^{N E T}>0$ is for a given $n$ (from direct inspection of the three areas depicted in Fig. 2); (b) reduces firm's CSR activities compatible with profitability (see the three vertical axes in Fig. 2).

A graphical representation of Result 1 is depicted in Fig. 2. With respect to the basic case of a monopolist in a network industry without CSR described in Fanti and Buccella (2016), the presence of CSR activities shrinks the area of profitability of the monopolist in the network industry. Nonetheless, the intuition behind the finding of Result 1 reflects that of those authors. It is obtained that $q^{R T M}<q^{S E B}$ and $p^{R T M}>p^{S E B}$ in the $(n, r)$ - space, the costs of production are identical regardless of the agenda, and independent of both the network intensity and the level of social engagement: in fact, $w^{R T M}=w^{S E B}$ independent of $r$ and $n$, while $c$ is exogenous. Given these results, the fact that $\Delta \pi^{N E T} \leq 0$ apparently seems puzzling. A closer analytical investigation reveals that, in equilibrium, for a given level of the union bargaining power, the monopolist produces at a point on the demand curve in which the price elasticity of demand under RTM is always larger than SEB, that is,
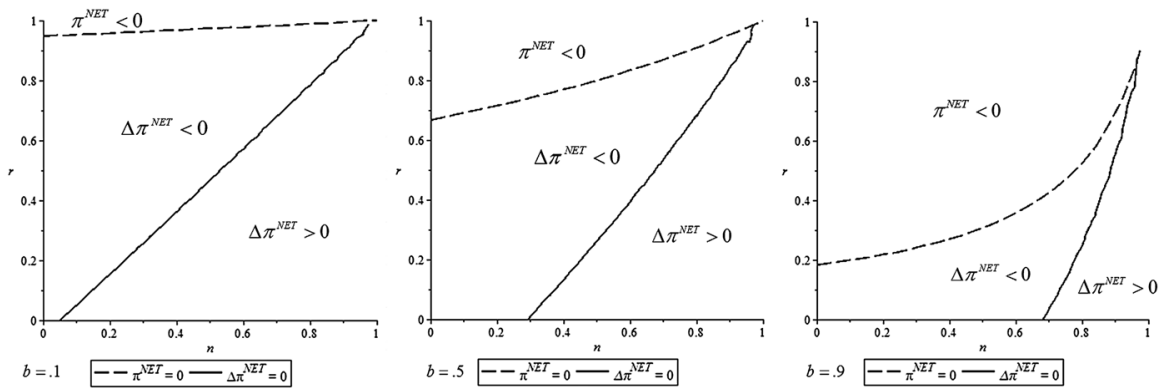

Fig. 2 Plot of the "threshold curves" $\Delta \pi^{N E T}=0$ and $\pi^{N E T}=0$ (i.e. $\left.r^{\mathrm{T}, N E T} \leq \frac{2(1-b)}{2-(1+n) b}\right)$ in the $(n, r)-$ space, for three given levels of $b=.1, .5, .9$. The curves are drawn for $a=1, c=w^{o}=0$. For all $(n, r)$ combinations below the dash curves $\pi^{N E T}=0, \pi^{N E T}>0$ 
$\varepsilon^{* R T M, N E T}(n, r)>\varepsilon^{* S E B, N E T}(n, r)$. Because the production costs are unaffected by CSR activities and network effects, the analysis of the profits differential mirrors that of the revenues differential.

Defining the marginal revenues differential of the two agendas as $\Delta M R^{N E T}=\left(M R^{S E B, N E T}-M R^{R T M, N E T}\right)$, algebraic passages leads to

$$
\Delta M R^{N E T}(n, r)=\underbrace{\left(p^{S E B, N E T}(n, r)-p^{R T M, N E T}(n, r)\right)}_{-}+\underbrace{\left(\frac{p^{R T M, N E T}(n, r)}{\varepsilon^{R T M, N E T}(n, r)}-\frac{p^{S E B, N E T}(n, r)}{\varepsilon^{S E B, N E T}(n, r)}\right)}_{+/-} \frac{>}{<} 0 .
$$

The first term of the above expression is unambiguously negative. On the other hand, the sign of the second term depends on the precise values of the parameters $(n, r)$, because $\frac{1}{\varepsilon^{* R T M, N E T}(n, r)}<\frac{1}{\varepsilon^{* S E B, N E T}(n, r)}$. In Fig. 2, the area in which $\Delta \pi^{N E T}>(<) 0$ defines the combination of the parameters in the $(n, r)$ - space such that the price differential effect between the two agendas is dominated by (dominates) the quantity variation effect on the monopolist's revenues.

The profit change is reversed (i.e., RTM is better) as CSR increases or network effect decreases. Therefore, it seems that these two effects are substitutable in profit change. A plausible explanation for this result is as follows. On one hand, the network effect will encourage the firms both to expand output and to charge higher price, which in turn will provide higher wage; on the other hand, CSR will also bolster output production and, therefore, induce the firms to reduce the final price, which will provide lower wage in negotiations. Therefore, when the network externalities are higher or the level of CSR activities is lower, both the firm and the union can enjoy higher welfare under SEB rather than RTM. ${ }^{11}$ On the other hand, by directly increasing the costs of production, the role of the parameter $b$ is to reduce the area of the monopolist's profitability, which is associated to a decreasing level of social engagement when the network effects are not sufficiently intense. ${ }^{12}$

\subsection{Special cases: a short discussion}

This subsection briefly discusses the following special cases: (1) $n=0$ and $r=0$; (2) $n>0$ and $r=0$; (3) $n=0$ and $r>0$. The interested reader can find a detailed discussion of those special cases in the supplement and Fanti and Buccella (2016).

\subsubsection{Standard model: $n=0$ and $r=0$}

This is the standard model in the presence of goods without consumption externalities and no CSR activities the early literature has analysed. In unionized industries, the monopolist always gains larger profits with RTM rather than SEB and EB (Dowrick 1990), and profits under efficient bargaining are identical, irrespective of whether the timing of the negotiations is sequential or simultaneous (Naylor

\footnotetext{
11 We are extremely grateful to an anonymous referee for having underlined this point.

12 See in Fig. 2 when $b=.9$, if $n$ is high and tends to unity, the CSR level can be adequately high.
} 
2003). This generates a conflict of interest between the firm and the union, because the latter prefers SEB to RTM. In addition, consumers and society always prefer SEB to RTM because $q^{R T M}<q^{S E B}$. However, if the monopolist has the right to select the agenda, it will choose RTM leading to a welfare-inferior outcome.

\subsubsection{No CSR activities in network industry: $n>0$ and $r=0$}

Fanti and Buccella (2016, pp. 96-99) have carried out an in depth analysis of this case. Those authors find that in a network industry without CSR rules, (1) a monopolist prefers SEB to RTM provided that the network effects are adequately intense, and the lower the union's bargaining power, the more likely the monopolist prefers SEB; and (2) the union always prefers SEB to RTM. Therefore, when the network effects are sufficiently strong, the monopolist and the union can agree on the SEB agenda. In addition, the wages under RTM and SEB are identical and independent of $n$. These results contrast the conventional wisdom of the standard model without consumption externalities and CSR activities above in which the monopolist always gains larger profits with RTM rather than SEB (Dowrick 1990), and profits under efficient bargaining are identical, regardless of whether the timing is sequential or simultaneous (Naylor 2003). Finally, the authors show that consumers and society are better off under SEB than RTM and, thus, when the network effect is adequately high, the SEB arrangement is Pareto-superior: the monopolist, workers and consumers prefer it.

\subsubsection{CSR in standard industries without network effects: $n=0$ and $r>0$}

In the absence of network effects, the key finding is that the monopolist prefers RTM to SEB, no matter the level of social engagement. However, this choice creates a conflict of interest with the union. Therefore, the adoption of CSR behaviours substantiates the conventional wisdom (see Naylor 2003) that a unionised monopolist prefers to negotiate only wages and keep off employment from negotiations. It can be easily checked that $q^{R T M}<q^{S E B}$ and $p^{R T M}>p^{S E B}$, while the production costs are identical and independent of the social concern level regardless of the agenda: in fact, $w^{R T M}=w^{S E B}$ with $r$ playing no role and $c$ exogenous. Finally, an analytical investigation reveals that both the consumer surplus and the social welfare are higher under the SEB agenda than the RTM, as expected. As a consequence, in the absence of network externalities, the monopolist adopting CSR rules and negotiating under the RTM agenda with the union always leads to a welfare-reducing effect larger than that of the SEB agenda.

\subsection{Welfare considerations}

At this point, it is of extreme interest to analyse the impact of CSR and network effects on consumer surplus and social welfare. The analysis focuses on the consumer surplus because it has a simpler expressions than social welfare and, given that those variables move exactly in the same direction, this choice does not affect 
the qualitative results. Defining, $\triangle C S^{N E T}=C S^{S E B, N E T}-C S^{R T M, N E T}$ and $\triangle S W^{N E T}=S W^{S E B, N E T}-S W^{R T M, N E T}$, an analytical investigation reveals, as expected, that, $\Delta C S^{N E T}>0, \Delta S W^{N E T}>0 .{ }^{13}$

Differentiation shows that $\frac{\partial C S^{R T M, N E T}}{\partial n}>0$ if $n \frac{<}{>} r_{1 n}^{R T M, N E T}$ and $\frac{\partial C S^{R T M, N E T}}{\partial r}>0$ : under the RTM agenda, the network effects have a positive effect on the consumer surplus (and social welfare) only if its level is lower than the social engagement, as the threshold $r_{1 n}^{R T M, N E T}$ illustrates; however, the CSR activities always have a positive impact on consumer surplus. The mixed derivatives show that $\frac{\partial^{2} C S^{R T M, N E T}}{\partial n \partial r}=\frac{\partial^{2} C S^{R T M, N E T}}{\partial r \partial n}>0$ if $2 n-1 \frac{<}{>} r_{2}^{R T M, N E T}$. However, given that $r_{2}^{R T M, N E T}<r_{1 n}^{R T M, N E T}$ for $n \in[0,1]$, it follows that the network effects have a complementarity effect on consumer surplus only up to a level of the CSR activities lower than the most beneficial value for consumers.

Concerning the SEB agenda, differentiation of consumer surplus expression with respect to the parameters $n$ and $r$ leads to $\frac{\partial C S^{S E B, N E T}}{\partial n} \frac{>}{<} 0$ if $\frac{2(n-b)}{2-b(3-n)}<r_{1 n}^{S E B, N E T}$ and $\frac{\partial C S^{S E B, N E T}}{\partial r}>0$ : under the SEB agenda, it exists a value of the network effects that would maximise the consumers' welfare. The analysis of the mixed derivatives shows that $\frac{\partial^{2} C S^{S E B, N E T}}{\partial n \partial r}=\frac{\partial^{2} C S^{S E B, N E T}}{\partial r \partial n} \frac{>}{<} 0$ if $\frac{4\left[1-2\left(n+b^{2}\right)\right]+2 b\left(n^{2}+4 n-1\right)}{b^{2}\left(n^{2}-2 n-3\right)+4(2 b-1)}>r_{2}^{S E B, N E T}$. Because it holds that $r_{2}^{S E B, N E T}<r_{1 n}^{S E B, N E T}$, the network externalities have a complementarity effect on consumer surplus (and social welfare) only for a level of the social engagement lower than that most beneficial for consumers.

Now, let us investigate the consequences of the monopolist's choice of the bargaining agenda. Because of the change in the firm's preference over the negotiation mode, the following result applies.

Result 2 Whenever the monopolist decides to adopt the RTM agenda in negotiations with the union, a social welfare-reducing effect takes place.

Given that for a given level of the network effects a relatively high firm's social concern induces the adoption of the RTM agenda, then CSR may imply, in contrast to the common belief, a reduction (instead of an increase) of both consumer surplus and social welfare as a whole.

A simple illustrative example (using the parametric set of Fig. 2, $a=1$, $c=w^{o}=0$ ) may clarify this crucial point. For the level of network effects $n=.5$, when the level of CSR engagement is not so high (that is, on the left of the threshold $\Delta \pi^{N E T}=0$ ), the monopolist prefers the SEB agenda. However, if the CSR level is adequately high, (beyond $\Delta \pi^{N E T}=0$ ), the firm switches its preference from the SEB to the RTM agenda, which leads to a drop both in the level of the consumer surplus and social welfare (the two variables move in unison), as Fig. 3 shows. Nonetheless, if the level of social engagement under the RTM agenda becomes sufficiently high, $\left.\quad C S^{R T M, N E T}\right|_{r \geq \Delta \pi^{N E T}=0} \geq\left. C S^{S E B, N E T}\right|_{r<\Delta \pi^{N E T}=0} \quad$ and $\left.\quad S W^{R T M, N E T}\right|_{r \geq \Delta \pi^{N E T}=0} \geq$ $\left.S W^{S E B, N E T}\right|_{r<\Delta \pi^{N E T}=0}$. For $b=.5, n=.5$, the switch of the agenda from SEB to RTM takes place at $r=.259$ (the level of the CSR such that $\Delta \pi^{N E T}=0$, while

\footnotetext{
13 Additional analytical and graphical details are available upon request from the authors.
} 

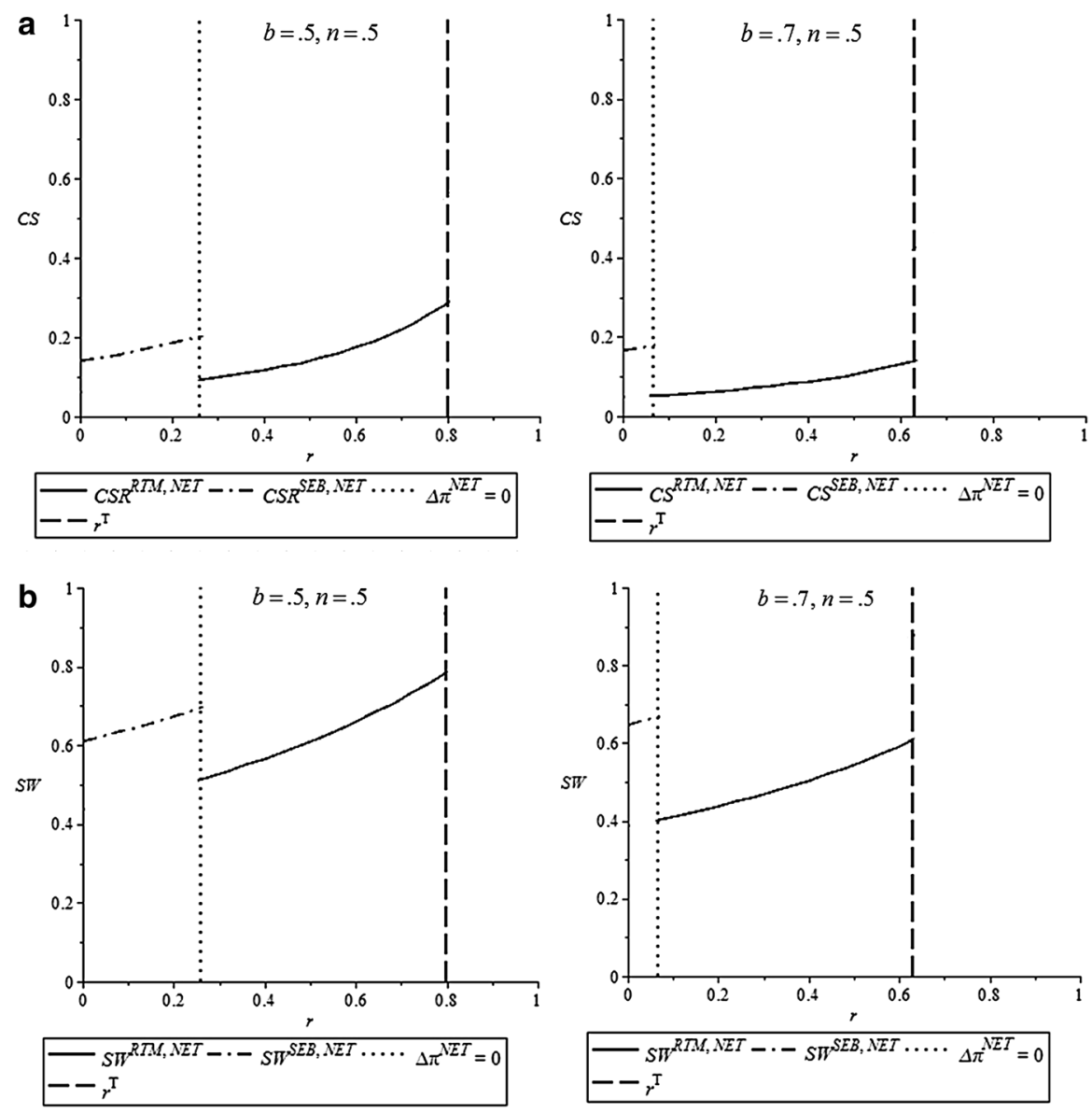

Fig. 3 Plot of the consumer surplus (up) and social welfare (down) as function of the CSR level, for two levels of the union bargaining power $b=.5, .7$, and for a level of the network effect $n=.5$. The other parameters are set at $a=1, c=w^{o}=0$

$\left.r^{T}=.8\right)$. It follows that $\left.C S^{S E B, N E T}\right|_{r=.259}=.20$ while $\left.C S^{R T M, N E T}\right|_{r=.259}=.09$ and $\left.S W^{S E B, N E T}\right|_{r=.259}=.695$ while $\left.S W^{R T M, N E T}\right|_{r=.259}=.513$ : the increase of the monopolist profits is more than offset by the reduction of the consumer surplus (the largest part of the social welfare drop) and union utility. Nonetheless, it can be checked that it exists a value of the social engagement such that the consumer surplus and the social welfare under the two agendas reaches the same level: for instance, at $r=.66,\left.C S^{R T M, N E T}\right|_{r=.66}=.20$ and $\left.S W^{R T M, N E T}\right|_{r=.66}=.695$.

On the other hand, when the union bargaining power is high enough, it may be that the change of the agenda is unequivocally welfare detrimental. In fact, for $b=.7, n=.5$, the monopolist changes the agenda from SEB to RTM at $r=.067$. It follows that $\left.C S^{S E B, N E T}\right|_{r=.067}=.18$ while $\left.C S^{R T M, N E T}\right|_{r=.067}=.05$ and, as regards social welfare, $\left.S W^{S E B, N E T}\right|_{r=.067}=.40$ while $\left.S W^{R T M, N E T}\right|_{r=.067}=.667$. However, it 
can be easily seen from Fig. 3, that in the feasibility area of the economy $\left(r \leq r^{\mathrm{T}}\right)$ it always holds that $C S^{R T M, N E T}<C S^{S E B, N E T}$ and $S W^{R T M, N E T}<S W^{S E B, N E T}$. The union bargaining power sharpens the fall in the consumer surplus and social welfare due to the change in the negotiation agenda. As a consequence, to equate the levels of those variables under SEB, the RTM agenda requires a level of CSR sufficiently high. However, when the union is adequately strong, whichever level of CSR compatible with the monopolist's profitability under RTM cannot suffice to attain the consumer surplus and social welfare levels under SEB.

\section{Conclusions}

This paper, motivated by the presence of unionised labour markets as well as the recent diffusion of both firm's social concerns and network goods (especially in Europe), investigates the bargaining agenda selection in a socially concerned unionised monopoly producing network goods. A cornerstone of the trade union economics argues that the most profitable negotiation agenda is the RTM one. However, recently Fanti and Buccella (2016) have shown that the network effects may reverse the established results of the previous literature: in fact, (1) a monopolist does not always prefer RTM, a SEB agreement can be preferred, (2) because the union and consumers always prefers the SEB agenda, the presence of network effects may solve the traditional conflict of interests between parties and achieve a Pareto-superior societal outcome.

Another feature characterising the current behaviour of many firms, in particular of those producing network goods, is their increasing interest for social themes, especially also accounting for the interests of their stakeholders such as consumer clients. In fact, it is crucial for a company building reputation and gaining trust from people to become successful: stakeholders and public believe that a good reputation is a priority to define whether a company is trustworthy and able to meet their expectation (Chan 2014).

This paper shows that when the firm's engagement in social activities-promoted also by policy-makers-is considered, the increasing social concern makes more likely that the firm, in a network industry, prefers the RTM agenda when those effects are not very intense, especially in the presence of a sufficiently weak union. Thus, the presence of strong firm's social responsibility tends to restore the conventional result of the trade-union economics that the monopolist prefers RTM. However, this leads to rather paradoxical conclusions as regards the widespread belief of the welfare-enhancing effects of socially responsible actions by firms. Indeed, since RTM is always welfare-inferior than SEB, this means that the monopolist engagement in CSR activities may lead to the unwelcome result of reaching the least social welfare level. This may result rather paradoxical to the extent that firm's social responsibility is promoted by policy makers. Therefore, our result sheds some light on so far unexplored effects of the promotion of social responsibility activities by policy makers when also labour markets are taken into account. 
Moreover, from our analysis, a clear testable hypothesis in industries with network externalities emerges: the RTM agenda should be more often present in the firms which have stronger social concerns.

A reasonable extension would be to investigate whether a monopoly firm should hire a manager to negotiate with the union and, if it is the case, how the findings of this paper may change.

Acknowledgements We are extremely grateful to the two anonymous referees for their valuable comments and suggestions that have substantially enhanced the clarity and quality of the paper. All remaining errors are, of course, our sole responsibility. The usual disclaimers apply.

Open Access This article is distributed under the terms of the Creative Commons Attribution 4.0 International License (http://creativecommons.org/licenses/by/4.0/), which permits unrestricted use, distribution, and reproduction in any medium, provided you give appropriate credit to the original author(s) and the source, provide a link to the Creative Commons license, and indicate if changes were made.

\section{Appendix}

\section{RTM institution}

At stage 3, maximising the monopolist's objective function, we obtain the following output function, for given consumers' expectations:

$$
q(y, w)=\frac{a-c-w+n y}{2-r} .
$$

From (8), after imposing the "rational expectations" condition at the second stage, we obtain the output level for given $w$ :

$$
q(w)=\frac{a-c-w}{2-r-n} .
$$

At the first stage of the game, under RTM, the monopolist-union bargaining unit selects $w$ to maximise the following generalised Nash product,

$$
\begin{aligned}
\max N(w) & =(W)^{1-b}(V)^{b} \\
& =\left[(a-w-q+n y-c) q+r \frac{\left(q^{2}-n y^{2}\right)}{2}\right]^{1-b}\left(\left(w-w^{\circ}\right) q\right)^{b}
\end{aligned}
$$

where $b$ represents the union's bargaining power.

After substitution of (9) in (10), and recalling the "rational expectations" condition $y=q$, maximisation of (10) w.r.t. $w$ leads to:

$$
w^{R T M}=\frac{2 w^{\circ}(1-b)+b(a-c)}{2}
$$

Substitution of (11) into (9) gives the equilibrium output 


$$
q^{R T M}=\frac{(2-b)\left(a-c-w^{\circ}\right)}{2(2-r-n)}
$$

Social welfare is defined by

$$
S W=\pi+C S+V
$$

Further substitutions of (10) and (11) in (1), (4), (5) and (13) lead to the equilibrium outcomes reported in Table 2.

\section{Sequential efficient bargaining institution}

Under SEB the monopolist-union bargaining unit maximises the following generalised Nash product,

$$
N=(W)^{1-b}(V)^{b}=\left[(a-w-q+n y-c) q+r \frac{\left(q^{2}-n y^{2}\right)}{2}\right]^{1-b}\left(\left(w-w^{\circ}\right) q\right)^{b} .
$$

Hence, the monopolist - union unit selects in the first stage $w$, then expectations realise and finally, in the third stage $l$, or equivalently $q$ is negotiated.

At the third stage, maximising (14) w.r.t. $q$, one gets the monopolist's output function:

$$
q(y, w)=\frac{(a-c-w+n y)+\sqrt{\left\{n^{2} y^{2}+2 n y\left[a-c-w-\frac{b r y(2-b)(2-r)}{2}\right]+(a-c-w)^{2}\right\}}}{(2-b)(2-r)} .
$$

From (15), after imposing the "rational expectations" condition at stage 2, we obtain the output level for given $w$ :

$$
q^{S E B}=\frac{2(a-c-w)}{2(2-r-n)-b[2-(1+n) r]} .
$$

In the first stage, after substitution of (16) in (14), the usual maximisation procedure w.r.t. $w$ leads to

$$
w^{S E B}=\frac{2 w^{\circ}(1-b)+b(a-c)}{2}
$$

It is easy to see that $w^{S E B}=w^{R T M}$. Further substitutions of (16) and (17) in (1), (4), (5) and (13) lead to the equilibrium outcomes reported in Table 2. 


\section{References}

Al Jazeera America. (2015). Unions make strides among Silicon Valley workforce, May 12, 2015. http:// america.aljazeera.com/articles/2015/5/12/unions-make-strides-among-silicon-valley-workforce.html. Accessed 28 Aug 2016.

Amir, R., \& Lazzati, N. (2011). Network effects, market structure and industry performance. Journal of Economic Theory, 146(6), 2389-2419.

Becchetti, L., Palestini, A., Solferino, N., \& Tessitore, M. E. (2014). The socially responsible choice in a duopolistic market: a dynamic model of "ethical product" differentiation. Economic Modelling, 43, 114-123.

Bhattacharjee, T., \& Pal, R. (2014). Network externalities and strategic managerial delegation in Cournot duopoly: is there a prisoners dilemma? Review of Network Economics, 12(4), 343-353.

BloombergBusinessweek. (2015). Microsoft's unionized contract workers get aggressive, April 30, 2015. http://www.bloomberg.com/news/articles/2015-04-30/microsoft-contract-workers-are-organizing. Accessed 28 Aug 2016.

Buccella, D. (2011). Corrigendum to "The strategic choice of union oligopoly bargaining agenda" [Int. J. Ind. Organ. 17, 1999 1029-1040]. International Journal of Industrial Organization, 29(6), 690-693.

Buccella, D., \& Fanti, L. (2015). On the strategic choice of union-oligopoly bargaining agenda: further results. Economics Research International, 2015, 530890-1-530890-7.

Bughin, J. (1999). The strategic choice of union-oligopoly bargaining agenda. International Journal of Industrial Organization, 17(7), 1029-1040.

Calveras, A., Ganuza, J. J., \& Llobet, G. (2007). Regulation, corporate social responsibility and activism. Journal of Economics and Management Strategy, 16(3), 719-740.

Carroll, A., \& Shabana, K. (2010). The business case for corporate social responsibility: a review of concepts research and practice. International Journal of Management Reviews, 12(1), 85-105.

Chan, L.Y., 2014. Corporate social responsibility of multinational corporations. Global Honors Theses, Paper 18, University of Washington Tacoma.

Chirco, A., \& Scrimitore, M. (2013). Choosing price or quantity? The role of delegation and network externalities. Economics Letters, 121(3), 482-486.

Dowrick, S. (1989). Union-oligopoly bargaining. The Economic Journal, 99(398), 1123-1142.

Dowrick, S. (1990). The relative profitability of Nash Bargaining on the labour demand curve or the contract curve. Economics Letters, 33(2), 121-125.

European Commission. (2001). Promoting a European framework for corporate social responsibility. COM (2001) 366 final, Brussels.

European Commission. (2006). Implementing the partnership for growth and jobs: making Europe a pole of excellence on corporate social responsibility. COM (2006) 136 final, Brussels.

European Commission. (2011). A renewed EU strategy 2011-14 for Corporate Social Responsibility. COM (2011) 681 final, Brussels.

Fanti, L. (2015). Union-firm bargaining agenda: Right-to-manage or efficient bargaining? Economics Bulletin, 35(2), 936-948.

Fanti, L., \& Buccella, D. (2015). Bargaining agenda, timing, and entry. MPRA Working Paper Series n. 64089.

Fanti, L., \& Buccella, D. (2016). Bargaining agenda and entry in a unionised model with network effects. Italian Economic Journal, 2(1), 1-31.

Frank, R. (2003). What price the moral high ground? Ethical dilemmas in competitive environments. Princeton: Princeton University Press.

Ganuza, J.J. (2012). Corporate social responsibility and social welfare. How to promote socially responsible business strategies. Els Opuscles del CREI No. 30. http://crei.cat/files/filesOpuscle/36/ 120321092822_ENG_30_ANG.pdf. Accessed 12 Jan 2016.

Goering, G. E. (2007). The strategic use of managerial incentives in a non-profit firm mixed duopoly. Managerial and Decision Economics, 28(2), 83-91.

Goering, G. E. (2008). Welfare impacts of a non-profit firm in mixed commercial markets. Economic Systems, 32(4), 326-334.

Goering, G. E. (2012). Corporate social responsibility and marketing channel coordination. Research in Economics, 66(2), 142-148. 
Goering, G. E. (2014). The profit-maximising case for corporate social responsibility in a bilateral monopoly. Managerial and Decision Economics, 35(7), 493-499.

Hoernig, S. (2012). Strategic delegation under price competition and network effects. Economics Letters, $117(2), 487-489$.

Horn, H., \& Wolinsky, A. (1988). Bilateral monopolies and incentives for merger. RAND Journal of Economics, 19(3), 408-419.

Katz, M., \& Shapiro, C. (1985). Network externalities, competition, and compatibility. American Economic Review, 75(3), 424-440.

Kopel, M., \& Brand, B. (2012). Social responsible firms and the endogenous choice of strategic incentives. Economic Modelling, 29, 982-989.

KPMG. (2013). The KPMG survey of corporate responsibility reporting 2013. Retrieved from https:// assets.kpmg.com/content/dam/kpmg/pdf/2015/08/kpmg-survey-of-corporate-responsibility-reporting2013.pdf.

Lambertini, L., \& Tampieri A. (2010). Corporate social responsibility in mixed oligopoly. Working Paper, No. 723, University of Bologna.

Lambertini, L., \& Tampieri A. (2011). On the stability of mixed oligopoly equilibria with CSR firms. Working Paper, No. 768, University of Bologna.

López, M. C., \& Naylor, R. A. (2004). The Cournot-Bertrand profit differential: a reversal result in a differentiated duopoly with wage bargaining. European Economic Review, 48(3), 681-696.

Manning, A. (1987a). An integration of trade union models in a sequential bargaining framework. The Economic Journal, 97(385), 121-139.

Manning, A. (1987b). Collective Bargaining Institutions and Efficiency. European Economic Review, $31(1-2), 168-176$.

McDonald, I. M., \& Solow, R. M. (1981). Wage bargaining and employment. American Economic Review, 71(5), 896-908.

Naylor, R. A. (2003). Economic models of union behavior. In J. T. Addison \& C. Schnabel (Eds.), International Handbook of Trade Unions (pp. 44-85). Cheltenham: Edward Elgar.

Pencavel, J. H. (1985). Wages and employment under trade unionism: microeconomic models and macroeconomic applications. Scandinavian Journal of Economics, 87(2), 197-225.

Reputation Institute. (2015). 2015 Global CSR RepTrak 100. http://www.reputationinstitute.com/ CMSPages/GetAzureFile.aspx ?path= $\sim$ medialmedialdocuments|2015-global-csr-reptrak-results. pdf\&hash=f375854351576541ae88db1e043e7417e9f057f83955bb3768454dd8e0417353\&ext=.pdf. Accessed 12 Jan 2016.

Spitzeck, H., \& Hansen, E. G. (2010). Stakeholder governance: How stakeholders influence corporate decision making. Corporate Governance: The International Journal of Business in Society, 10(4), 378-391.

Valach, M. (2015). Profit maximization, social welfare and creating opportunities for corporate social responsibility in Slovakia. Paper presented at the Joint International Conference 2015, 27-29 May 2015, Bari, Italy. http://www.toknowpress.net/ISBN/978-961-6914-13-0/papers/ML15-344.pdf. Accessed 12 Jan 2016. 